Anita Gębska Kuczerowska ${ }^{1,4 *}$, Hanna Rozenek ${ }^{2}$, Monika Frajnt-Dąrowska ${ }^{3}$, Daniel Rabczenko ${ }^{4}$, Jolanta Banasiewicz², Robert Gajda

\title{
FEATURES OF PERSONALITY AND PROFESSIONAL BURNOUT SYNDROME OF PHYSICIANS - ANALYSIS BASED ON QUESTIONNAIRES STUDIES
}

\section{CECHY OSOBOWOŚCI A WYPALENIE ZAWODOWE LEKARZY - ANALIZA WYNIKÓW BADAŃ ANKIETOWYCH}

\author{
${ }^{1}$ Cardinal Stefan Wyszynski University in Warsaw, Collegium Medicum, \\ ${ }^{2}$ Medical University in Warsaw, Psychology and Medical Communication Dept., \\ ${ }^{3}$ Cardinal Stefan Wyszynski University in Warsaw, Psychology Institute, \\ ${ }^{4}$ National Institute of Public Health, Warsaw \\ ${ }^{5}$ Gajda-Med Medical Center \\ ${ }^{1}$ Uniwersytet Kardynała Stefana Wyszyńskiego w Warszawie, Collegium Medicum, \\ ${ }^{2}$ Uniwersytet Medyczny w Warszawie, Departament Psychologii i komunikacji medycznej, \\ ${ }^{3}$ Uniwersytet Kardynała Stefana Wyszyńskiego w Warszawie, Instytut Psychologii, \\ ${ }^{4}$ Narodowy Instytut Zdrowia Publicznego w Warszawie \\ ${ }^{5}$ Gajda-Med Medical Center
}

\begin{abstract}
This observational study was ordered by the Medical Practitioners' Chamber in Warsaw.

THE OBJECTIVE of the study was to evaluate the problem of professional burnout of physicians correlation between professional burnout and features of personality.

MATERIAL AND METHODS. Professional burnout was considered relative to different features of personality. This study was initially carried out from 2005-2008, but further analysis of burnout and personality was carried out from 2017-2018. The research tools were anonymous, validated questionnaires. The sample size was based on the size of the population - the registry of the Regional Chamber of Medical Practitioners and literature on burnout prevalence. The respondents' work places were randomly selected from the Mazovian District register. RESULTS. The test on burnout was completed by 378 respondents, while 62 subjects completed a personality test. Results showed that burnout syndrome was an occupational problem for healthcare workers. Professional burnout affected as many as $42 \%$ of respondents $(n=158)$. It affected two age groups in particular: physicians up to 31 years old and individuals aged 41-50. Moreover, neuroticism was found to be significantly related to burnout syndrome.
\end{abstract}

CONCLUSION. burnout syndrome is common among professionally active medical practitioners, and neuroticism may be correlated with burnout syndrome.

Key words: mental health, health service research, burnout, public health, physicians

\section{STRESZCZENIE}

Badanie obserwacyjne zostało zlecone przez Izbę Lekarską w Warszawie.

CELEM PRACY była ocena problemu wypalenia zawodowego lekarzy oraz określenie zależności pomiędzy osobowością a wypaleniem zawodowym.

MATERIAŁ I METODY. Analizowano obecność wypalenia zawodowego w odniesieniu do różnych cech osobowości. Badania przeprowadzono początkowo w latach 2005-2008, jednak dalszą analizę wypalenia zawodowego i osobowości przeprowadzono w latach 2017-2018. Narzędziami badawczymi były anonimowe, walidowane kwestionariusze. Wielkość próby określono w oparciu o liczebność populacji lekarzy - ewidencji 
Okręgowej Izby Lekarskiej oraz dane z literatury nt. rozpowszechnienia zjawiska wypalenia. Miejsca pracy respondentów zostały wybrane losowo z rejestru mazowieckiego.

WYNIKI. Test na występowanie zjawiska wypalenia wypełniło 378 respondentów, a test osobowości 62 osoby. Wyniki wykazały, że zespół wypalenia zawodowego stanowił problem zawodowy dla lekarzy.. Wypalenie zawodowe zdiagnozowano aż u $42 \%$ respondentów $(n=158)$, w szczególności dwóch grup wiekowych: lekarzy do 31 roku życia oraz osób w wieku 41-50 lat. Ponadto stwierdzono istotny związek neurotyczności z zespołem wypalenia zawodowego.

WNIOSKI. Zespół wypalenia jest powszechnym problemem wśród grupy czynnych zawodowo lekarzy, a neurotyczność może być skorelowana z zespołem wypalenia.

Słowa kluczowe: zdrowie psychiczne, badania stużby zdrowia, wypalenie zawodowe, zdrowie publiczne, lekarze

\section{INTRODUCTION}

Burnout syndrome affects individuals who are involved in occupations duties associated with services crucial to society. This has distinct implications for medical practitioners, patients, and managers of healthcare system institutions $(1,2)$.This paper is primarily focused on the determinants of burnout syndrome, also known as exhaustion syndrome or burnout effect. This phenomenon is not only an individual psychological problem but also as a social problem (3). According to definition "Burn-out is a syndrome conceptualized as resulting from chronic workplace stress that has not been successfully managed. It is characterized by three dimensions: feelings of energy depletion or exhaustion; increased mental distance from one's job, or feelings of negativism or cynicism related to one's job; and reduced professional efficacy. Burn-out refers specifically to phenomena in the occupational context and should not be applied to describe experiences in other areas of life."(ICD.XI- QD-85)

Burnout syndrome might occur in individuals who practice occupations human service professions which are occupations that demand both - complete dedication, close interpersonal contact with patients' in critical/difficult health status, and simultaneously high professional attitude. Burnout typically affects professionals such as; teachers, physicians, nurses, therapists, social workers, police officers, or priests (4). Burnout syndrome is also seen in performanceoriented individuals who dedicate themselves entirely to work. Sometimes, the problem is referred to as an "excessive dedication disease" (5).

Currently, many researchers believe that job-related stress, which results from a mismatch between the requirements of the job and the individual's resources, accounts for the development of burnout syndrome and is a precondition for its occurrence (3). H. Sęk asserts that the generalized and repeated failures experienced by an individual trying to overcome stress at work are of crucial to the development of burnout syndrome (6). In the case of medical practitioners (3), stress may result

\section{WSTĘP}

Zespół wypalenia zawodowego często dotyczy osób wykonujących zawody związane z kluczowymi dla społeczeństwa usługami. Wykonywanie aktywności typu „pomocowego” ma wyraźne konsekwencjedla lekarzy, pacjentów i menadżerów w instytucjach systemu ochrony zdrowia $(1,2)$. W niniejszej pracy skoncentrowano się przede wszystkim na uwarunkowaniach syndromu wypalenia, znanego również jako zespół wyczerpania lub efekt wypalenia. Zjawisko to jest nie tylko indywidualnym problemem psychologicznym, ale także społecznym (3). Zgodnie z definicja wypalenie zawodowe jest określane jako rezultat przewlektego stresu, który nie zostat skutecznie opanowany. Wyróżnia się 3 zasadnicze wymiary wypalenia zawodowego: poczucie wyczerpania energii lub zmęczenia, zwiększenie dystansu emocjonalnego $w$ stosunku do pracy lub uczucie negatywizmu badź cynizmu zwiazanego z praca, obniżona efektywność (ICD XI - QD-85).

Wypalenie zawodowe może występować u osób wykonujących zawody medyczne, które wymagają; dużego poświęcenia, bliskiego kontaktu interpersonalnego z osobami znajdującymi się w trudnym/ krytycznym położeniu zdrowotnym, a jednocześnie wysokiego profesjonalizmu.Wypalenie zawodowe zazwyczaj dotyczy takich specjalistów jak np.: nauczyciele, lekarze, pielęgniarki, terapeuci, pracownicy socjalni, policjanci, czy księża.(4). Syndrom wypalenia dotyczy często osób zorientowanych na wydajność, które całkowicie poświęcają się pracy. Czasami problem ten określany jest jako „choroba nadmiernego zaangażowania się" (5).

Obecnie wielu naukowców uważa, że stres związany z pracą, a wynikający z niedopasowania wymagań zawodowych do zasobów danej osoby, odpowiada za rozwój syndromu wypalenia i jest warunkiem koniecznym do jego wystąpienia (3). H. Sęk twierdzi, że uogólnione i powtarzające się niepowodzenia w przezwyciężaniu stresu $\mathrm{w}$ pracy mają kluczowe znaczenie dla rozwoju syndromu wypalenia (6). W przypadku lekarzy (3) stres może wynikać z warunków, w jakich 
from the conditions in which they perform their work (e.g. work organization, time pressure, red tape, and inadequate renumeration), interpersonal factors (e.g. relationships with other staff members, interactions with patients, and communication with families of patients), individual factors (e.g. self-esteem, sense of effectiveness, sense of control, and reactivity). $M$. Anczewska and colleagues reviewed the results of prior research and noted that the impact of individual factors on the development of burnout syndrome has not been researched as often as the impact of situations. Even less research analyzed the relationship between burnout syndrome and personality features such as hardness, external control, avoidance of stress, low self-esteem, and high levels of neuroticism (7).

In psychology, personality is a theoretical structure used to describe the general features of an individual. These include behaviors, hobbies, attitudes, and specific features that define how an individual reacts (8). There are many definitions and theories related to this notion. One of the best-known was developed by Costa and McCrae. The Five-Factor Model of Personality posits the existence of five basic personality features, neuroticism, extraversion, agreeableness, conscientiousness, and openness to experience. The NEO-Five Factor Inventory (NEO-FFI) is used to evaluate these traits and is often used in empirical research $(9,10)$.

\section{AIM}

This study aimed to diagnose burnout in a group of medical practitioners and analyze the correlation between burnout syndrome and personality features. This paper evaluated how these "Big Five" personality traits relate to professional burnout.

\section{MATERIALS AND METHODS}

The respondents of this study were 445 medical practitioners registered with the Regional Chamber of Medical Practitioners (2005-2008), from random selected medical centers service providers. The extended analysis of professional burnout and personality was carried out from 2017-2018, based on research data. Of those 445 active medical practitioners, 378 were administered the Burnout Scale (BOS, Skala Wypalenia Sit - Polish version), while 62 individuals were administered the personality test (NEO-FFI). The distribution of NEO-FFI questionnaires was limited to a small group of respondents $(20 \%, \mathrm{~N}=76$, response rate $=82 \%$ ). The size of the sample was estimated based on the assumption that approximately $30 \%$ of the entire group experienced the burnout effect $(11,12)$. The estimation precision was $5 \%$, in wykonują swoją pracę (np. organizacja pracy, presja czasu, biurokracja, nieodpowiednie wynagradzanie), czynników interpersonalnych (np. relacje z innymi członkami personelu, interakcje z chorymi, komunikacja z rodzinami chorych), czynników indywidualnych (np. samoocena, poczucie skuteczności, poczucie kontroli i reaktywności). M.Anczewska i wsp.dokonując przeglądu wyników wcześniejszych badań stwierdzili, że wpływ poszczególnych czynników indywidualnych na rozwój syndromu wypalenia nie był badany tak często, jak wpływ czynników sytuacyjnych. Jeszcze mniej badań dotyczyło związku między syndromem wypalenia a cechami osobowościowymi, takimi jak wytrzymałość, kontrola zewnętrzna, unikanie stresu, niska samoocena i wysoki poziom neurotyczności (7).

W psychologii - „osobowość” jest strukturą teoretyczną- służącą do opisu ogólnych cech jednostki. Należą do nich zachowania, hobby, postawy i specyficzne cechy, które określają sposób reagowania jednostki (8). Istnieje wiele definicji i teorii związanych $\mathrm{z}$ tym pojęciem. Jedna z najbardziej znanych została opracowana przez Coste i McCrae. Tzw. Pięcioczynnikowy Model Osobowości zakłada istnienie pięciu podstawowych cech osobowości: neurotyczności, ekstrawersji, ugodowości, sumienności i otwartości na doświadczenie. Autorzy teorii są jednocześnie twórcami Inwentarza Osobowości (NEO-Five Factor Inventory NEO-FFI), który jest wykorzystywany w badaniach empirycznych do oceny tych cech $(9,10)$.

\section{CEL}

Celem pracy była diagnoza zespołu wypalenia zawodowego w grupie lekarzy i analiza korelacji między nasileniem objawów wypalenia zawodowego a uwarunkowaniami osobowościowymi. W artykule oceniono, jak cechy osobowości, należące do tzw.,Wielkiej Piątki"korespondują z poziomem wypalenia zawodowego.

\section{MATERIAŁY I METODY}

Badaniami objęto 445 lekarzy zarejestrowanych w Okręgowej Izbie Lekarskiejw Warszawie w latach 2005-2008 z losowo wybranych placówek świadczenia usług medycznych. Pogłębioną analizę, na podstawie zebranych wówczas danych, na temat wypalenia zawodowego i osobowości przeprowadzono w latach 2017-2018.Spośród aktywnych zawodowo medyków - 378 wypełniło Skalę Wypalenia Sił (SWS), a 62 osoby - dodatkowo test osobowości (NEO-FFI). Dystrybucja kwestionariuszy NEO-FFI była ograniczona do wąskiej grupy respondentów $(20 \%, \mathrm{~N}=76$,zwrot $\mathrm{n}=82 \%$ ). Liczebność całej próby oszacowano zakłada- 
used questionnaire's tool BOS. Given the criteria, the minimum sample size was 320 individuals. Before conducting this study, a pilot study was first executed (focused on testing the methodology and scope). As for ethical considerations, the Regional Chamber of Physicians granted ethics approval. Before answering the questionnaires, respondents were told that the survey was voluntary and anonymous. Afterward, they were asked to provide informed consent and the coded results were individually available to the respondents (on dedicated website).

The BOS is a Polish test developed by St. Steuden and $W$. Okta and was used in this study to appraise the extent of burnout. The tool is designed for occupationally active adults and is composed of 66 statements that represent five factors: emotional control reduction, loss of dedication, reduction of action effectiveness, narrowing of interpersonal relations, and physical fatigue. Respondents evaluated each of the statements using a five-point scale, where five was the highest grade and indicated maximum intensity of the negative condition, and one indicated that the situation/condition described by a given statement did not exist with reference to the respondent. Factors I and II appraised the extent to which an individual his or her emotional ability to handle situations related to their job. Factor III described dissatisfaction with the actions that were taken and a lack of measurable effort on the part of the individual. Factor IV indicated an unwillingness to initiate contact with others. Finally, Factor V established the extent of physical fatigue. These five factors provided a way to appraise the degree to which impacted an individual's functioning in the workplace. Unprocessed results were the total points within each scale. The lowest score possible was 66, while the highest score possible was 330 . There were no standard values and interpretations, so unprocessed results were used for description. The theoretical average was 132, and the standard deviation was set as 8 . Sten scores were used to evaluate the results. The BOS test produces similar results to other burnout measurement tools, such as the Maslach Burnout Inventory (MBI) test (13). The demographics of the participants who answered this tool are presented in table I.

The Polish adaptation of the NEO-FFI used in this study (was developed by Zawadzki, Strelau, Szczepaniak, and Śliwińska). This questionnaire is designed to diagnose the personality features of adults aged 15 and older. The questionnaire is comprised of 60 items: five scales with 12 items each. Each of the answers was graded from zero to four points, where a higher result indicated a greater intensity of a given feature. Unprocessed indicators were transformed into sten scores (standardized). Separate standards were jąc, że zjawisko wypalenia dotyczy około $30 \%$ populacji medyków, przy stosowanym teście SWS $(11,12)$. Dokładność oszacowania liczebności próby wyniosła $5 \%$. Biorąc pod uwagę te kryteria, minimalna liczebność próby respondentów wynosiła 320 osób. Przed badaniem przeprowadzono najpierw badanie pilotażowe (ukierunkowane na przetestowanie metodologii i zakresu). Okręgowa Izba Lekarska udzieliła akceptacji etycznej oraz wsparcia na przeprowadzenie badania. Przed przystąpieniem do badania, respondenci zostali poinformowani, że jest ono dobrowolne i anonimowe. Następnie poproszono ich o wyrażenie świadomej zgody, a każdy z badanych miał indywidualny dostęp do swoich kodowanych wyników (na dedykowanej projektowi stronie).

Skala Wypalenia Sił (SWS) jest polskim testem, opracowanym przez St.Steuden i W.Okte oraz została wykorzystana do oceny poziomu zaawansowania procesu wypalenia zawodowego. Narzędzie przeznaczone jest dla osób dorosłych aktywnych zawodowo i składa się z 66 wypowiedzi, które reprezentują pięć czynników: obniżenie kontroli emocjonalnej, utratapodmiotowego zaangażowania, obniżenie efektywności działania, zawężenie kontaktów interpersonalnych oraz zmęczenie fizyczne. Badani ustosunkowują się do każdego twierdzenia zaznaczając odpowiedź na pięciostopniowej skali. Najwyższa ocena na skali wynosi 5 punktów i dotyczy odpowiedzi TAK oznaczając tym samym maksymalne nasilenie negatywnego stanu. Ocena 1 za odpowiedź NIE oznacza, że sytuacja/ stan opisywany danym stwierdzeniem u danej osoby nie występuje.Wspólne ujęcie czynnika I i II pozwala na ocenę stopnia, w jakim jednostka utraciła zdolność emocjonalnego radzenia sobie $\mathrm{z}$ sytuacją związaną z pracą zawodową. Czynnik III opisuje brak zadowolenia z podejmowanych działań oraz brak wymiernych wysiłków podejmowanych przez jednostkę. Czynnik IV wskazuje na utratę ochoty do inicjowania i podejmowania kontaktów z innymi, a czynnik $\mathrm{V}$ opisuje stopień fizycznego zmęczenia. Tych pięć czynników umożliwia ocenę wpływu pracy zawodowej na ogólne funkcjonowanie jednostki. Wyniki surowe były sumą punktów w każdej skali. Najniższy możliwy wynik to 66 punktów, natomiast najwyższy możliwy to 330 . $\mathrm{W}$ interpretacji wyników korzysta się z wyniku surowego - średnia teoretyczna wynosi 132, a odchylenie standardowe zostało ustalone na poziomie 8 . Test SWS dostarcza podobnych wyników jak inne narzędzia do pomiaru wypalenia, takie jak test Inwentarz Wypalenia Maslach (MBI - Maslach Burnout Inventory) (13). Dane demograficzne uczestników, którzy wzięli udział w badaniu, zostały przedstawione w tabeli I.

W badaniu wykorzystano polską adaptacjękwestionariusza NEO-FFI (autorzy adaptacji Zawadzki, Strelau, Szczepaniak i Śliwińska). Kwestionariusz 
Table I. Respondent Characteristics: gender and age

Tabela I. Charakterystyka respondentów: płeć i wiek

\begin{tabular}{|c|c|c|c|c|c|c|c|}
\hline \multirow{3}{*}{$\begin{array}{l}\text { BOS Test - filled in } \\
\text { correctly }\end{array}$} & \multicolumn{7}{|c|}{ Gender } \\
\hline & & \multicolumn{2}{|c|}{ Females } & \multicolumn{2}{|c|}{ Males } & \multicolumn{2}{|c|}{ no data } \\
\hline & $\mathrm{N}$ & $\mathrm{n}$ & $\%$ & $\mathrm{n}$ & $\%$ & $\mathrm{n}$ & $\%$ \\
\hline No & 67 & 37 & 67.3 & 18 & 32.7 & 12 & 17.9 \\
\hline Yes & 378 & 186 & 60.8 & 120 & 39.2 & 72 & 19.0 \\
\hline \multirow[t]{3}{*}{ Total } & 445 & 223 & 61.8 & 138 & 38.2 & 84 & 18.9 \\
\hline & \multicolumn{7}{|c|}{ Age } \\
\hline & $\mathrm{N}$ & Average & $\mathrm{SD}$ & Median & Min & Max & no data \\
\hline No & 38 & 49.8 & 16.8 & 46 & 26 & 79 & 29 \\
\hline Yes & 222 & 46 & 11.5 & 46 & 27 & 80 & 156 \\
\hline Total & 260 & 46.6 & 12.4 & 46 & 26 & 80 & 185 \\
\hline
\end{tabular}

followed based on gender (females and males) and age (five age categories: 15 - 19, 20 - 29, 30 - 39, 40 - 49, 50 - 80). The results were categorized as follows: 1 to 3 stens were low, 4 to 6 were moderate, and 7 to 10 were high.

Finally, the correlation between the results of the BOS and NEO-FFI questionnaires was assessed using Pearson's linear correlation and Spearman rank correlation. For all analyses, a level of significance of $\alpha=0.05$ was adopted. Calculations were made using the SPSS 12.0 statistical package.

\section{RESULTS}

The analysis revealed that among 378 medical practitioners, $158(42 \%)$ were affected by professional burnout syndrome.(Tab. I).

Correlations between the BOS and NEO-FFI and its components are presented in the table II. An analysis of the correlation matrix showed a statistically significant positive association among all components of the BOS ( $<<0.001$ for correlations); meanwhile, the weak correlation among components of the NEOFFI scale. The correlations between almost all pairs of measures - the components of NEO-FFI scale and total value of BOS scale were not statistically significant, and the absolute values of coefficients were small. Only neuroticism was positively and statistically significant correlated $(r=0.770 ; p<0.001)$ with total value of BOS scale, while extraversion, openness, and agreeableness were negatively correlated but not statistically significant. Neuroticism was also statistically significant correlated with all five factors of BOS: emotional control, work dedication, action effectiveness, interpersonal relations and physical fatigue. Therefore, only the higher the level of neuroticism implies the higher the level of professional burnout and its components. No other statistically significant correlations were found between the scales. przeznaczony jest do diagnozy cech osobowości osób dorosłych (powyżej 15 r.ż). Składa się z 60 pozycji: pięć skal po 12 pozycji każda. Każda odpowiedźoceniana jest w skali od zera do czterech punktów, przy czym wyższy wynik wskazuje na większe nasilenie danej cechy. Wyniki surowe zostały przekształcone we wskaźniki stenowe (standaryzowane). Normy sporządzone są w zależności od płci (kobiety i mężczyźni) i wieku (pięć kategorii wiekowych: 15 - 19, 20 - 29, $30-39,40-49,50-80$ ). Wyniki zostały podzielone na kategorie w następujący sposób: od 1 do 3 stenów były niskie, od 4 do 6 średnie, a od 7 do 10 wysokie.

Ostatecznie korelacja pomiędzy wynikami kwestionariuszy SWS i NEO-FFI została oceniona za pomocą korelacji liniowej Pearsona i korelacji rang Spearmana. Dla wszystkich analiz przyjęto poziom istotności $\alpha=0,05$. Obliczenia wykonano przy użyciu pakietu statystycznego SPSS 12.0.

\section{WYNIKI}

Wśród 378 lekarzy, 158 (42\%) było dotkniętych problemem wypalenia zawodowego (Tab.I).

Korelacje pomiędzy skalami SWS i NEO-FFI oraz ich składowymi przedstawiono w tabeli II. Analiza macierzy korelacji wykazała istotny statystycznie, dodatni związek pomiędzy wszystkimi składowymi SWS $(p<0,001)$ oraz słabsze korelacje pomiędzy składowymi skali NEO-FFI. Korelacje pomiędzy, prawie wszystkimi parami miar składowych skali NEO-FFI a całkowitą wartością skali SWS nie były istotne statystycznie, a bezwzględne wartości współczynników korelacji były niewielkie. Jedynie neurotyczność była dodatnio skorelowana i istotnie statystycznie (r $=0,770 ; p<0,001)$ z całkowitą wartością skali SWS, natomiast pozostałe cechy - ekstrawersja, otwartość i ugodowość były skorelowane ujemnie (i nieistotnie statystycznie). Neurotyczność była dodatnio skorelowana ze wszystkimi składowymi skali SWS (kontrolą emocjonalną, efektywnym działaniem, zobowiąza- 
Table II. Correlation between the extent of burnout and features of personality: Professional burnout problem versus features of medical practitioners' personality $(\mathrm{N}=378 / \mathrm{n}=62)$

Tabela II. Korelacja pomiędzy wypaleniem zawodowym a cechami osobowości: Problem z wypalenia zawodowego a cechy osobowości lekarzy.

\begin{tabular}{|c|c|c|c|c|c|c|c|c|c|c|c|c|}
\hline & & 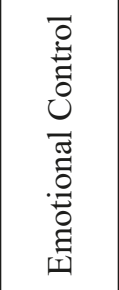 & 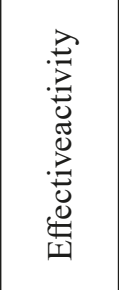 & 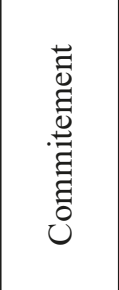 & 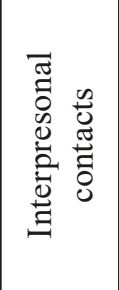 & 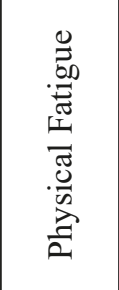 & 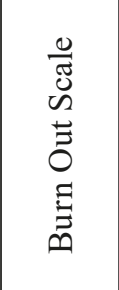 & 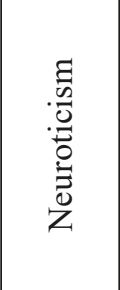 & 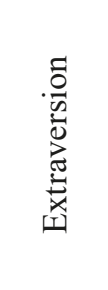 & 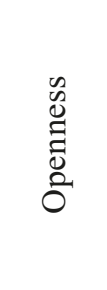 & 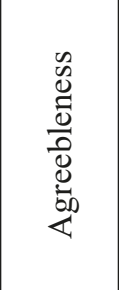 & 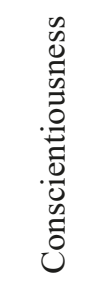 \\
\hline \multirow{3}{*}{ Emotional Control } & $\mathrm{N}$ & 378 & 378 & 378 & 378 & 378 & 378 & 378 & 378 & 378 & 378 & 378 \\
\hline & Rho & - & 0.747 & 0.712 & 0.736 & 0.650 & 0.917 & 0.737 & -0.194 & -0.049 & -0.064 & 0.010 \\
\hline & $\mathrm{p}$ & - & $<0.001$ & $<0.001$ & $<0.001$ & $<0.001$ & $<0.001$ & $<0.001$ & 0.242 & 0.772 & 0.701 & 0.953 \\
\hline \multirow{3}{*}{ Effective activity } & $\mathrm{N}$ & 378 & 378 & 378 & 378 & 378 & 378 & 378 & 378 & 378 & 378 & 378 \\
\hline & Rho & 0.747 & - & 0.732 & 0.631 & 0.570 & 0.858 & 0.739 & -0.281 & 0.036 & 0.089 & -0.208 \\
\hline & $\mathrm{p}$ & $<0.001$ & - & $<0.001$ & $<0.001$ & $<0.001$ & $<0.001$ & $<0.001$ & 0.088 & 0.828 & 0.595 & 0.21 \\
\hline \multirow{3}{*}{ Commitement } & $\mathrm{N}$ & 378 & 378 & 378 & 378 & 378 & 378 & 378 & 378 & 378 & 378 & 378 \\
\hline & Rho & 0.712 & 0.732 & - & 0.651 & 0.526 & 0.827 & 0.637 & -0.284 & -0.174 & -0.282 & 0.052 \\
\hline & $\mathrm{p}$ & $<0.001$ & $<0.001$ & - & $<0.001$ & $<0.001$ & $<0.001$ & $<0.001$ & 0.084 & 0.296 & 0.086 & 0.754 \\
\hline \multirow{3}{*}{$\begin{array}{l}\text { Interpresonal } \\
\text { contacts }\end{array}$} & $\mathrm{N}$ & 378 & 378 & 378 & 378 & 378 & 378 & 378 & 378 & 378 & 378 & 378 \\
\hline & Rho & 0.736 & 0.631 & 0.651 & - & 0.616 & 0.805 & 0.710 & -0.190 & -0.171 & -0.254 & 0.039 \\
\hline & $\mathrm{p}$ & $<0.001$ & $<0.001$ & $<0.001$ & - & $<0.001$ & $<0.001$ & $<0.001$ & 0.253 & 0.304 & 0.123 & 0.818 \\
\hline \multirow{3}{*}{ Physical Fatigue } & $\mathrm{N}$ & 378 & 378 & 378 & 378 & 378 & 378 & 378 & 378 & 378 & 378 & 378 \\
\hline & Rho & 0.650 & 0.570 & 0.526 & 0.616 & - & 0.709 & 0.734 & -0.134 & 0.027 & -0.068 & 0.045 \\
\hline & $\mathrm{p}$ & $<0.001$ & $<0.001$ & $<0.001$ & $<0.001$ & - & $<0.001$ & $<0.001$ & 0.423 & 0.874 & 0.683 & 0.79 \\
\hline \multirow{3}{*}{ Burn Out Scale } & $\mathrm{N}$ & 378 & 378 & 378 & 378 & 378 & 378 & 378 & 378 & 378 & 378 & 378 \\
\hline & Rho & 0.917 & 0.858 & 0.827 & 0.805 & 0.709 & - & 0.770 & -0.244 & -0.085 & -0.145 & -0.002 \\
\hline & $\mathrm{p}$ & $<0.001$ & $<0.001$ & $<0.001$ & $<0.001$ & $<0.001$ & - & $<0.001$ & 0.139 & 0.611 & 0.385 & 0.991 \\
\hline \multirow{3}{*}{ Neuroticism } & $\mathrm{N}$ & 62 & 62 & 62 & 62 & 62 & 62 & 62 & 62 & 62 & 62 & 62 \\
\hline & Rho & 0.737 & 0.739 & 0.637 & 0.710 & 0.734 & 0.770 & - & -0.421 & 0.037 & -0.102 & -0.093 \\
\hline & $\mathrm{p}$ & $<0.001$ & $<0.001$ & $<0.001$ & $<0.001$ & $<0.001$ & $<0.001$ & - & 0.001 & 0.775 & 0.429 & 0.472 \\
\hline \multirow{3}{*}{ Extraversion } & $\mathrm{N}$ & 62 & 62 & 62 & 62 & 62 & 62 & 62 & 62 & 62 & 62 & 62 \\
\hline & Rho & -0.194 & -0.281 & -0.284 & -0.190 & -0.134 & -0.244 & -0.421 & - & 0.268 & 0.398 & 0.319 \\
\hline & $\mathrm{p}$ & 0.242 & 0.088 & 0.084 & 0.253 & 0.423 & 0.139 & 0.001 & - & 0.036 & 0.001 & 0.011 \\
\hline \multirow{3}{*}{ Openness } & $\mathrm{N}$ & 62 & 62 & 62 & 62 & 62 & 62 & 62 & 62 & 62 & 62 & 62 \\
\hline & Rho & -0.049 & 0.036 & -0.174 & -0.171 & 0.027 & -0.085 & 0.037 & 0.268 & - & 0.334 & 0.113 \\
\hline & $\mathrm{p}$ & 0.772 & 0.828 & 0.296 & 0.304 & 0.874 & 0.611 & 0.775 & 0.036 & - & 0.008 & 0.38 \\
\hline \multirow{3}{*}{ Agreebleness } & $\mathrm{N}$ & 62 & 62 & 62 & 62 & 62 & 62 & 62 & 62 & 62 & 62 & 62 \\
\hline & Rho & -0.064 & 0.089 & -0.282 & -0.254 & -0.068 & -0.145 & -0.102 & 0.398 & 0.334 & - & 0.331 \\
\hline & $\mathrm{p}$ & 0.701 & 0.595 & 0.086 & 0.123 & 0.683 & 0.385 & 0.429 & 0.001 & 0.008 & - & 0.009 \\
\hline \multirow{3}{*}{ Conscientiousness } & $\mathrm{N}$ & 62 & 62 & 62 & 62 & 62 & 62 & 62 & 62 & 62 & 62 & 62 \\
\hline & Rho & 0.010 & -0.208 & 0.052 & 0.039 & 0.045 & -0.002 & -0.093 & 0.319 & 0.113 & 0.331 & - \\
\hline & $\mathrm{p}$ & 0.953 & 0.21 & 0.754 & 0.818 & 0.79 & 0.991 & 0.472 & 0.011 & 0.38 & 0.009 & - \\
\hline
\end{tabular}

\section{DISCUSSION}

Despite the fact that 12 years have passed since the survey on professional burnout of physicians in Mazovia - due to changes in the healthcare system and the urgent need to emphasize the importance of the niem, kontaktami interpersonalnymi, zmęczeniem fizycznym).Zatem im wyższy poziom neurotyczności, tym wyższy poziom wypalenia zawodowego i jego składowych. Nie stwierdzono żadnych innych statystycznie istotnych korelacji między skalami. 
problem - the extended analysis has been undertaken on previous collected data.("The professional burnout physicians - the problem and the challenge for public health", NIPH, 2011). The BOS test was able to estimate the prevalence and severity of burnout among medical practitioners. Different results have been found in other research.n the United States, research conducted by Merritt - Hawkins on behalf of The Physicians Foundation demonstrated that 78\% of the 8,774 medical practitioners surveyed displayed typical burnout symptoms (14). Thediscrepancies come from the difference in assessment tools, as well as the specificity of burnout phenomenon. In our study the questionnaire, measured the gradual progress of the professional burnout, from its presence, through the high risk to its absence (the analysis included only data persons with burnout, not with high risk). While Merritt - Hawkins used a self-assessment tool that directly asked respondents how often they have feelings of professional burnout in their medical career. Despite these discrepancies, it is undeniable that burnout poses a serious threat to the healthcare system. These claims echo those of a report by the Harvard T.H. Chan School of Public Health, Harvard Global Health Institute, Massachusetts Medical Society, and Massachusetts Health and Hospital Association (1).

Another author, S.W. Yates cited the same values of the prevalence of professional burnout of physicians in the USA as in our study, while pointing the problem of the precision in the assessment of the phenomenon scale (15).

With great interest in the professional burnout phenomenon - there are also negative opinions about the possibility of its diagnosis. These comments relate to the imprecise definition of the burnout syndrome itself, which therefore limits the differentiate diagnosis with other health problems (16).

Similar to the results found by Merritt-Hawkins, the study sponsored by the Harvard School of Public Health asserted that burnout can lead to early retirement or departure from medicine altogether $(1,14)$. Professional burnout is also the cause of a wide range of other social and economic consequences, which first arise from an inability of coping with stress $(15,16)$.

Among the respondents of this study, the extent of burnout corresponded to the level of neuroticism. Neuroticism is defined as a tendency to react to stressful events with much "negative affectivity and emotional distress" (17). Moreover, it results in the perception of certain situations as job-related burdens (18). Many experts in the field of research on burnout problems emphasize this correlation $(4,19,20)$.

Conversely, some argue that the correlation between personality structure and burnout syndrome cannot

\section{DYSKUSJA}

Mimo, że od badania wypalenia zawodowego lekarzy na Mazowszu minęło już 12 lat - ze względu na zmiany w systemie ochrony zdrowia i pilną potrzebę podkreślenia wagi problemu, podjęto pogłębioną analizę zebranych wówczas danych ("Wypalenie zawodowe lekarzy jako problem i wyzwanie dla zdrowia publicznego", NIZP, 2011). Badanie z wykorzystaniem SWS pozwoliło na ocenę częstości występowania i stopnia nasilenia wypalenia Uzyskane wyniki dot. rozpowszechnienia wypalenia zawodowego wśród lekarzy były odmienne niż w innym badaniu. W Stanach Zjednoczonych badania przeprowadzone przez Merritt-Hawkins na zlecenie The Physicians Foundation wykazały, że 78\% z 8774 badanych lekarzy wykazuje typowe objawy wypalenia (14). Rozbieżności te wynikają z różnic w narzędziach oceny, jak i specyfiki badanego zjawiska. W naszym badaniu wykorzystano narzędzie diagnostyczne) którym oceniono stopniowe zaawansowanie problemu wypalenia zawodowego od stwierdzenia jego obecności, przez stan wysokiego zagrożenianim, do jego braku (analiza objęła wyłącznie dane osób z wypaleniem, bez wysokiego ryzyka). Natomiast w badaniu Merritt-Hawkins wykorzystano narzędzie samooceny, w którym zapytano respondentów wprost - jak często mają poczucie wypalenia zawodowego wykonując pracę zawodową. Pomimo tych rozbieżności nie da się zaprzeczyć, że syndrom wypalenia stanowi poważne zagrożenie dla systemu opieki zdrowotnej. Twierdzenia te powtarzająs ię $\mathrm{w}$ raporcie Harvard T.H. Chan School of Public Health, Harvard Global Health Institute, Massachusetts Medical Society oraz Massachusetts Health and Hospital Association (1).Inny autor S.W. Yates przytoczył wartości rozpowszechnienia wypalenia zawodowego wśród lekarzy w USA takie same jak w naszym badaniu, wskazując jednocześnie na problem precyzyjności wocenie skali zjawiska (15).

Przy dużym zainteresowaniu zjawiskiem wypalenia zawodowego - pojawiają się również negatywne opinie na temat możliwości jego diagnozowania. Uwagi często dotyczą nieprecyzyjnej definicji samego zespołu wypalenia, przez co ograniczne są możliwość różnicowania diagnozy z innymi problemami zdrowotnymi (16).

Podobnie jak wyniki badania Merritt-Hawkins, w badaniu sponsorowanym przez Harvard School of Public Health stwierdzono, że wypalenie może prowadzić do wcześniejszego przejścia na emeryturę lub całkowitego porzucenia medycyny $(1,14)$. Wypalenie zawodowe stanowi również przyczynę wielu innych problemów społeczno-ekonomicznych, których źródłem jest nieumiejętność radzenia sobie ze stresem $(15,16)$. 
be categorically demonstrated, but co-occurrence of burnout, neuroticism, and introversion may be related to other factors (21). Some scientists believe that, to a considerable extent, neuroticism is an inheritable trait. However, the impact of environmental factors is also important. Moreover, neuroticism is considered to be one of the most important phenomena in public health, since, as B.B. Lahey claims, it seems to be correlated with a broad spectrum of mental and physical health problems (22). For example, neuroticism may be considered a risk factor for the development of traumatic stress following exposure to critical situations (18).

In this study, neuroticism demonstrated correlation with all components of the BOS: emotional control reduction, loss of dedication, reduction of action effectiveness, narrowing of interpersonal relations, and physical fatigue. This may be related to the negative emotionality mentioned above, since neuroticism is typically accompanied by irritation, loss of interest in work, negative attitudes towards the environment, and feelings of overload and fatigue (23). Neuroticism also affects both perception of and techniques used to handle stress. The extent of the inability to adapt and/or of emotional imbalance is demonstrated by the tendency to experience negative emotions (fear, anger, and guilt) and sensitivity to psychological stress (perception). Highly neurotic individuals react intensely to stress and handle it through avoidance and negation (24). Burnout also impacts the quality and effectiveness of work output; this, in turn, is related to social costs, since a burnt-out employee is less dedicated to work and less effective in terms of work performance. This might result in decreased patient satisfaction and increased occurrence of medical malpractice, which may threaten the health of patients (25).

While personality is a relatively stable structure, the issues of overloading (mentally and physically) by the work of medical workers depend on the healthcare system organization, which is worth remembering when managing human resources. Since neuroticism is very strongly linked to feeling negative emotions as a result of overload - it can induce the problem of professional burnout - as many studies have shown $(26,27$. At the same time, neurotic workers have a tendency to think catastrophically and are more exposed to tiredness, and also tend to lose confidence in their own resources for coping with stress. Consequently, these lead to a faster decrease in their energy and to rise both stress and exhaustion (28).

The negative consequences of burnout syndrome have been explained. As such, it is important to develop policies to reduce its occurrence. Burnout syndrome may be a consequence of stress experienced in the work place. Thus, stress prevention might prevent burnout
Poziom wypalenia zawodowego wśród lekarzy uczestniczących w niniejszym badaniu koresponduje z poziomem neurotyczności. Jest ona definiowana jako tendencja do reagowania na stresujące wydarzenia wysokim poziomem negatywnej afektywności i niepokoju emocjonalnego (17). Co więcej, przyczynia się ona do postrzegania pewnych sytuacji jako obciążeń związanych z pracą (18). Wielu ekspertów w dziedzinie badań nad problemami wypalenia podkreśla tę zależność $(4,19,20)$.

Pojawiają się też poglądy, że związku między strukturą osobowości a podatnością na wypalenie nie można jednoznacznie wykazać, ale obserwuje się pewne tendencje, które uwidaczniają związek pomiędzy współwystępowaniem wypalenia oraz neurotyczności i introwersji (21). Niektórzy naukowcy uważają, że w znacznym stopniu neurotyczność jest cechą dziedziczną. Istotny jest również wpływ czynników środowiskowych. Co więcej, neurotyczność jest uważana za jeden z najistotniejszych czynników wobszarze zdrowia publicznego, ponieważ, jak twierdzi B.B.Lahey, wydaje się być skorelowana $\mathrm{z}$ szerokim spektrum problemów zdrowia psychicznego i fizycznego (22). Na przykład neurotyczność może być uważana za czynnik ryzyka rozwoju stresu traumatycznego po ekspozycji na sytuacje krytyczne (18).

W niniejszym badaniu wykazano korelację neurotyczności ze wszystkimi składowymi SWS: zmniejszeniem kontroli emocjonalnej, utratą zaangażowania, zmniejszeniem skuteczności działania, zawężeniem relacji międzyludzkich i zmęczeniem fizycznym. Może to być związane ze wspomnianą wyżej negatywną emocjonalnością, bowiem neurotyczności zazwyczaj towarzyszy drażliwość/irytacja, utrata zainteresowania pracą, negatywne nastawienie do otoczenia oraz uczucie przeciążenia i zmęczenia (23). Neurotycznośćnie pozostaje również bez wpływu na sposób postrzegania sytuacji stresowych i techniki radzenia sobie ze stresem. O stopniu niezdolności do adaptacji i/lub braku równowagi emocjonalnej świadczy tendencja do odczuwania negatywnych emocji (strach, złość i poczucie winy) oraz wrażliwość na stres psychologiczny (percepcja). Osoby o wysokim stopniu neurotyczności intensywnie reagują na stres i radzą sobie z nim poprzez unikanie i negację (24). Wypalenie ma również wpływ na jakość i efektywność wyników pracy, co z kolei wiąże się z kosztami społecznymi, ponieważ wypalony pracownik jest mniej oddany pracy i mniej efektywny w jej wykonywaniu. Może to $\mathrm{w}$ przypadku pracowników medycznych skutkować zmniejszeniem zadowolenia chorego i zwiększeniem liczby przypadków niewłaściwego postępowania lekarskiego, co może zagrażać zdrowiu chorych (25).O ile osobowość stanowi w miarę stabilną strukturę, o tyle kwestie przeciążenia (psychicznego i fi- 
syndrome. As part of primary prevention, it is proposed that work conditions and organizations be improved. Secondary prevention includes the development of various staff competencies. For example, individuals may be taught stress-handling techniques. Tertiary prevention includes providing support to employees who experience intensive stress or health problems as a consequence of stress (29). Prevention and attempts to overcome burnout syndrome might take place at the individual or institutional levels (30). M. Anczewska and colleagues have found that educational programs and workshops focused on identifying and coping with burnout have been developed in Poland and around the world. The employee rejuvenation and retention program developed by $J$. Cole is an example. Employer responsibilities, including demonstration of gratitude, recognition of outstanding performance, and definition of occupational roles, may help mitigate stress $(7,31)$.

In the healthcare setting, work may be improved through the optimal allocation of patients to each doctor and an appropriate organization of the workplace (e.g. break time, time for passive relaxation, effective work shift rotations, shorter working hours, aesthetically pleasing workplace, and proper lighting). Other proposed solutions include backing up support groups, organizing problem-solving meetings that enable an exchange of viewpoints and assessment of difficulties, and offering training in relaxation techniques and interpersonal skills (7).

Among this study's respondents, two age groups were found to be the most affected by burnout syndrome: those 25 to 31 years and 41 to 50 years. This may be due to the tension at work experienced by young medical practitioners. $S$. de Bever et al. believed that the most difficult challenge for young general practitioners (GP) in Denmark is relationship with patients (32). These conflicts become a source of stress and lead to burnout upon extended exposure. Older medical practitioners, on the other hand, might experience stress related to the simultaneous fulfillment of occupational and familial duties.

As such, young GPs should focus on developing communication and assertiveness skills, since their patients are often older individuals, and younger GPs might have a problem communicating with them regarding appointment schedules, unnecessary visits, test instructions, and medication prescriptions. For older medical practitioners, emphasis should be placed on communicating and coping with feelings of stress, since this group experiences self-destructive reactions to stress more frequently. These include addiction, excessive work, and a lack of balance between work and personal life (33).

Some authors propose that focus be placed on measures of personality by "BIG five", especially zycznego) pracą pracowników medycznych są zależne od organizacji systemu ochrony zdrowia, o czym warto pamiętać przy zarządzaniu zasobami ludzkimi. Ponieważ neurotyzm jest bardzo silnie związany z odczuwaniem negatywnych emocji w wyniku przeciążenia - może on indukować coraz wyraźniej problem wypalenia zawodowego - na co wskazuje wiele badań $(26,27)$. Jednocześnie osoby neurotyczne mając tendencje do myślenia katastroficznego oraz wyższą podatność na zmęczenie, również szybciej tracą wiarę we własne zasoby radzenia sobie ze stresem. Skutkuje to szybszym spadkiem energii i narastaniem napięcia oraz zmęczenia (28).

Syndrom wypalenia może być konsekwencją stresu odczuwanego w miejscu pracy, dlatego w ramach profilaktyki pierwotnej proponuje się poprawę warunków i organizacji pracy. Profilaktyka wtórna polega na rozwijaniu różnych kompetencji pracowników. Na przykład, można wskazywać i zachęcać jednostki do stosowania różnych technik radzenia sobie ze stresem. Profilaktyka trzeciorzędowa polega na udzielaniu wsparcia pracownikom, którzy doświadczają intensywnego stresu lub problemów zdrowotnych w wyniku stresu (29). Profilaktyka i próby przezwyciężenia syndromu wypalenia mogą mieć miejsce na poziomie indywidualnym lub instytucjonalnym (30). M. Anczewska i wsp. dokonując przeglądu wytycznych dotyczących interwencji prozdrowotnych wykazuje, że w Polsce i na świecie opracowywane są programy edukacyjne i warsztaty dotyczące identyfikacji objawów wypalenia i radzenia sobie z nim. Przykładem jest opracowany przez $J$. Cole program wspomagający aktywizację i utrzymanie pracowników, przez łagodzenie stresu oraz podkreślanie osiągnięć, określenie ról zawodowych $(7,31)$.

W celu poprawy warunków pracy w opiece zdrowotnej proponowane są działania takie jak: optymalna liczba pacjentów przyporządkowana pracownikom, odpowiednia organizacja pracy (przerwy w pracy, bierny wypoczynek, rotacyjna zmiana personelu, skrócenie czasu pracy, odpowiednie przygotowanie stanowisk z uwzględnieniem walorów estetycznych, prawidłowego oświetlenia itp.). Ponadto proponuje się wspieranie rozwoju grup wsparcia, organizację spotkań problemowych pozwalających na wymianę poglądów i oszacowanie trudności, treningi relaksacyjne i treningi umiejętności interpersonalnych (7).

Wśród respondentów tego badania dwie grupy wiekowe zostały uznane za najbardziej dotknięte syndromem wypalenia: od 25 do 31 lat i od 41 do 50 lat. Może to wynikać z napięcia w pracy, jakiego doświadczają młodzi lekarze. S. de Bever et al. uważają, że najtrudniejszym wyzwaniem dla młodych lekarzy rodzinnych (GP) w Danii są relacje z pacjentami (32). Konflikty te stają się źródłem stresu i prowadzą do wypalenia przy 
on neuroticism. Furthermore, they assert that neuroticism might be more flexible and sensitive to direct interventions than believed in the past (34). There are very few research papers concerning the effectiveness of interventions to reduce the level of neuroticism. Nevertheless, in a randomized pilot study, researchers found that the level of neuroticism decreased after administering an intervention founded on mindfulness-based cognitive therapy (MBCT) (35).

Australian medical practitioners acknowledge the problems caused by professional burnout and propose changing the text of the Hippocratic Oath. These practitioners claim that the current wording of the Oath contributes to the dissemination of burnout effect in the environment of medical practitioners. An updated version of the Oath is expected to have a statement declaring that one's duty is not limited to the health of patients, but also extends to one's own mental and physical health. Similar provisions have also been incorporated into the Genève Declaration (amended in 2017), in what is known as the Modern Hippocratic Oath. To provide patients with top-quality medical services, medical practitioners should not neglect the care of their own moods, comfort, and health.

\section{CONCLUSIONS}

The analysis of the scores by the tests BOS and NEO-FFI founded that neuroticism is correlated with burnout syndrome. It seems that both neuroticism and professional burnout have strong implications individually for medical staff and generally for human resources status in the healthcare system. Both occupational overload and neuroticism, personality features, are contributing to professional burnout. Such findings point that professional burnout is still a major challenge because of (psychological and physical) overloaded, especially in Covid-19 pandemic time.

\section{ACKNOWLEDGMENTS}

We would like to dedicate this work to the memory of the late Dr Andrzej Włodarczyk, who supported research (2005-2008) at the Warsaw Medical Chamber. We would like to thank all the consultants at several stages of the project, especially the authors of the Test SWS - Prof. St. Steuden i Dr. W. Okła. We would like to express our special thanks to all physicians who had actively supported the research, hoping for a good direction of change in healthcare system.

\section{REFERENCES}

1. Jha AK, Iliff AR, Chaoui AA, Defossez S, Bombaugh MC, Miller YR. A Crisis in health care: dłuższym narażeniu. Natomiast starsi lekarze moga doświadczać stresu związanego z jednoczesnym wypełnianiem obowiązków zawodowych i rodzinnych.

Być może w przypadku młodych lekarzy rodzinnych należałoby szczególnie położyć nacisk na umiejętności z zakresu komunikacji i asertywności.Ich pacjentami są często ludzie starsi i młodzi lekarze mogą mieć problem z porozumieniem się z nimi, czy odmawianiem nieumówionych lub nieuzasadnionych wizyt, zlecaniem badań, leków itp.

Z kolei w przypadku starszych lekarzy większy nacisk należałoby położyć na radzenie sobie ze stresem i komunikację, bowiem w tej grupie częściej pojawiają się destrukcyjne reakcje na stres np. uzależnienia, przepracowanie, brak równowagi pomiędzy życiem zawodowym a osobistym (33).

Niektórzy autorzy proponują skoncentrowanie się na neurotyczności jako uwarunkowaniu osobowości istotnie zwiększającym ryzyko wypalenia zawodowego. Co więcej, twierdzą oni, że neurotyczność może być bardziej elastyczna i wrażliwa na bezpośrednie ingerencje niż uprzednio sądzono (34). Wydaje się sensowne przygotowanie specjalnych programów profilaktycznych wspierających osoby wysoce neurotyczne. Istnieje jednak niewiele prac badawczych dotyczących skuteczności działań ograniczających poziom neurotyczności, niemniej w randomizowanym badaniu pilotażowym przeprowadzonym w sposób losowy stwierdzono, że poziom neurotyczności zmniejszył się po zastosowaniu interwencji ukierunkowanej na terapię poznawczą opartą na świadomości (MindulnessBasedCognitiveTherapy - MBCT) (35).

Australijscy lekarze dostrzegają problemy spowodowane wypaleniem zawodowym i proponują zmianę odwiecznego brzmienia przysięgi Hipokratesa, twierdząc iż w dotychczasowej wersji przyczynia się do rozpowszechnienia wypalenia zawodowego w środowisku lekarzy. W nowej wersji ma się w niej znaleźć zapis zobowiązujący lekarza nie tylko do dbałości o zdrowie pacjentów, lecz także o swoje własne samopoczucie, zdrowie psychiczne i fizyczne. Podobne zapisy zawarto także w znowelizowanej w 2017 roku Deklaracji Genewskiej,nazywanej współczesną przysięgą Hipokratesa. Aby zapewnić pacjentowi opiekę medyczną na najwyższym poziomie, lekarz nie może zaniedbywać troski o własne dobre samopoczucie, komfort i zdrowie.

\section{WNIOSKI}

Analiza wyników za pomocą testów SWS i NEO -FFI wykazała, że neurotyczność jest skorelowana z zespołem wypalenia zawodowego. Wydaje się, że zarówno neurotyczność, jak i wypalenie zawodowe mają poważne konsekwencje zarówno indywidualnie 
A call to action on physician burnout. http://www. massmed.org/News-and-Publications/MMSNews-Releases/Physician-Burnout-Report-2018/ (accessed on 21February 2019).

2. Świątkowska B. Zagrożenia zawodowe pracowników opieki zdrowotnej: Co wiemy i co możemy zrobić? Occupational hazards of healthcare workers: What is known and what can be done. Probl Hig Epidemiol. 2010; 91: 522-529.

3. Pustułka-Piwnik U, Ryn Z, Krzywoszański Ł, Stożek J. Zespół wypalenia zawodowego u fizjoterapeutów a zmienne demograficzne i organizacyjne. Burnout syndrome of physical therapeutists - demographic and organizational factors. Medycyna Pracy. 2014; 65: 453-462.

4. Maslach C, Schaufeli WB, Leiter MP. Job burnout. Annual Rev of Psychol. 2001; 52: 397-422.

5. Sapilak BJ, Kurpas D, Steciwko AF, Melon M. Wypalenie zawodowe personelu medycznego - problem wciąż aktualny. Metody oceny i przeciwdziałania $w$ ramach oddziałów dializacyjnych. Problemy Lekarskie 2006; 45: 81-3.

6. Sęk H. ed. Wypalenie zawodowe przyczyny, mechanizmy, zapobieganie. Warszawa, PWN. 2000; $1-256$.

7. Anczewska M, Świtaj P, Roszczyńska J. Wypalenie zawodowe. Occupationalburn-out. Post Psych Neurol. 2005; 14: 67-77.

8. Grabski B, Gierowski K. Zaburzenia osobowościróżne spojrzenia i próby ich integracji. Personality disorders - different outlooks and attempts at their integration. Psych Pol 2012; 66: 829-44.

9. De La Fuente-Solana EI, Urquiza JLG, Cañadas GR, Albendin L. Burnout and its relationship with personality factors in oncology nurses. Eur J Oncol Nurs 2017; 30: 91-99.

10. Cano-Garcia F, Muñoz P, Carrasco M. Personality and contextual variables in teacher burnout. Personal a. Individ Differ 2005; 38: 929-940.

11. Rotenstein LS, Torre M, Ramos MA, et al. Prevalence of Burnout Among Physicians: A Systematic Review. JAMA. 2018; 320(11):1131-1150, doi:10.1001/jama.2018.12777

12. Soler JK,Yaman H, Esteva M.et al. Burnout in European family doctors: The EGPRN study. Family Practice. 2008; 25: 245-65. 10.1093/fampra/ cmn038.

13. SteudenS, Okła W. ed. Tymczasowy podręcznik do skali wypalenia sił wersja eksperymentalna. Lublin: Zakład Psychologii Klinicznej KU. 1998.

14. 2018 Survey of America's Physicians: Practice Patterns and Perspectives The Physicians Foundation by Merritt Hawkins. Available online:https://physiciansfoundation.org/ wp-content/uploads/2018/09/physicianssurvey-results-final-2018.pdf (accessed on 21 February2019). dla personelu medycznego, jak i ogólnie dla stanu zasobów ludzkich w systemie opieki zdrowotnej. Zarówno przeciążenie zawodowe, jak i neurotyczność, czyli cechy osobowości, przyczyniają się do wypalenia zawodowego. Takie ustalenia wskazują, że wypalenie zawodowe jest nadal głównym wyzwaniem z powodu przeciążenia (psychicznego i fizycznego), a zwłaszcza w czasie pandemii Covid-19.

\section{PODZIĘKOWANIA}

Pracę dedykujemy pamięci zmarłego dr n. med. Andrzeja Włodarczyka, który wspierał badanie (20052008) w Warszawskiej Izbie Lekarskiej. Dziękujemy również wszystkim osobom, z którymi konsultowaliśmy projekt na wielu jego etapach, a w szczególności autorom testu Wypalenia Sił (SWS ) - Paniom Prof. St. Steuden i Dr. W. Okła. W szczególności dziękujemy wszystkim lekarzom, którzy aktywnie poparli to badanie $\mathrm{z}$ nadzieją na dobry kierunek zmian w systemie ochrony zdrowia.

15. Yates S W. Physician Stress and Burnout. Am J Med, 2020;133(2):160-164. ISSN 0002-9343, doi. org/10.1016/j.amjmed.2019.08.034

16. Burisch M. Das Burnout-Syndrom: Theorie der inneren Erschöpfung - ZahlreicheFallbeispiele HilfenzurSelbsthilfe. Springer-Verlag, 27.12.2005

17. Ceobanau NC, Mairean C. The Relation between Personality Traits, Social Support and Traumatic Stress. Revista de CercetaresiInterventieSociala. 2015; 48: 17-31.

18. Newbury-Birch D, Kamali F. Psychological stress, anxiety, depression, job satisfaction, and personality characteristics in preregistration house officers. Postgrad Med J 2001; 77: 109-111.

19. Bühler KE, Land T. Burnout and personality in extreme nursing: an empirical study. Schweizer Archiv Neurol Psych 2004; 155: 35-42.

20. Shimizutani M, Odagiri Y, Ohya Y, Shimomitsu T, Kristensen TS, Maruta T, Iimori M. Relationship of Nurse Burnout with Personality Characteristics and Coping Behaviors. Industrial Healt 2008; 46: 326-335.

21. Walkiewicz M, Sowińska K, Taras M. Wypalenie zawodowe wśród personelu medycznego przegląd literatury. Burnout in medical profession - a literaturę review. Przegl Lek 2014; 71: 263-269.

22. Lahey BB. Public Health Significance of Neuroticism. Am Psychol.2009; 64: 241-256.

23. Poraj G. Osobowość jakopredyktor zawodowego wypalania się nauczycieli. Med Pracy 2009; 60: 273-282. 
24. SchneiderT. The role of neuroticism and psychosocial stress responses. J of Exper Soc Psychol 2004; 40: 795-804.

25. LeiterMP,HarvieP, FrizzellC. The Correspondence of Patient Satisfaction and Nurse Burnout. Soc Sci Med 1998; 47: 1611-161.

26. Gunthert, K.C., Cohen, L., Armelli, S. The role of neuroticism in daily stress and coping. $\mathrm{J}$ Person Soc Psychol 1999; 77 (5): 1087- 1100. doi. org/10.1037/0022-3514.77.5.1087

27. Gonzalez, J.L., Lopez-Lopez, A., AlonsoFernandez, M., Ciudad, N., Matias- Pompa, B., Moreno- Jimenez, B. Fatigue as moderator of relationship between personality and the affective dimensions of well- being. JHappStud 2014; 15: 1363- 1376. doi.org/10.1007/s10902-013-9480-5

28. Kangas, M., Montgomery, G.H. The role of cognitive, emotional and personality factors in the experience of fatigue in university and community sample. Psychol and Health 2011; 26, supplement 1: 1-19.

29. Vahey DC, Aiken LH, Sloane DM, Clarke SP, Vargas D. Nurse Burnout and Patient Satisfaction. Med Care 2004; 42: 57-66.

30. Waszkowska M, Merecz D, Drabek M. Programy prewencji stresu zawodowego - strategie, techniki, ocena skuteczności. Część II. Prewencja stresu zawodowego na poziomie organizacji. Med Pracy 2010; 61: 191-204.
31. Cole J. An ounce of prevention beats burnout. HR Focus 1999; 76: 6-13.

32. de Bever S, van Rhijn SC, van Dijk N. et al. Professionals' perspectives on factors affecting GP trainees' patient mix: results from an interview and focus group study among professionals working in Dutch general practice. BMJ Open. 2019; 9: 12. :e032182. Published 2019 Dec 15. doi:10.1136/ bmjopen-2019-032182

33. Medscape National Physician Burnout \& Depression Report 2018 https://www.medscape. com/slideshow/2018-lifestyle-burnoutdepression-6009235 (accessed on 20 February 2019).

34. Barlow DH, Sauer-Zavala S, Carl J R, Bullis JR, Ellard KK. The Nature, Diagnosis, and Treatment of Neuroticism. Clin Psychol Sci 2013; 2: 344-365.

35. Armstrong L, Rimes KA. Mindfulness-Based Cognitive Therapy for Neuroticism (Stress Vulnerability): A Pilot Randomized Study. Behav Ther 2016; 47: 287-298.

Received: 19.10.2020

Accepted for publication: 16.11 .2020

Otrzymano:19.10.2020

Zaakceptowano do publikacji: 16.11 .2020

Address for correspondence:

Adres do korespondencji:

36. email-agkucz@vp.pl 